\title{
Income Inequality and Noncash Food Assistance Program in Central Java Province
}

\author{
By \\ Yusuf Munandar \\ Fiscal Policy Agency, Ministry of Finance, Republic of Indonesia \\ Corresponding Author: yusufmunandar@yahoo.co.id
}

Submission: August 11, 2021; Accepted: June 21, 2021

\begin{abstract}
One measure of income inequality that is often used is the Gini Coefficient. In Central Java Province, the income inequality in March 2019 was increasing compared to income inequality in September 2018. To reduce this income inequality, the government is focusing on increasing government spending in the field of social assistance, including NonCash Food Assistance (Bantuan Pangan Non Tunai/BPNT). Thus, this study aims to calculate and obtain a reduction in the Gini Coefficient as a result of the implementation of the BPNT program in the Central Java Province of Indonesia. This study uses the Counter Factual Analysis (CFA) method and the March 2019 Susenas data. This study concludes that the implementation of the BPNT program in 2019 is quite effective in reducing the level of income inequality in the Central Java Province of Indonesia, which is able to reduce the Gini Coefficient of Central Java Province by $-1.20 \%$. The implementation of the BPNT program was able to make the expenditure of the lower class population increase faster than the expenditure of upper and middle class population. The implementation of the BPNT program changes the map of the income inequality level of 35 districts/cities in the Central Java Province of Indonesia but does not change the map of the level of income inequality between urban and rural areas in the Central Java Province of Indonesia. In addition, the implementation of the BPNT program in the Central Java Province of Indonesia has not been able to change the category of income inequality in the Central Java Province of Indonesia, namely that it remains in the moderate category. This study recommends improvements in terms of the target recipients of BPNT, the quality of the human resources of the companions, the time for receiving assistance, the quality of rice, and the readiness of e-warong in 35 districts/cities in the Province of Central Java, Indonesia.
\end{abstract}

Keywords: Non-Cash Food Assistance, Income Inequality, Gini Coefficient, Counter Factual Analysis.

\section{ABSTRAK}

Salah satu ukuran ketimpangan pendapatan yang sering digunakan adalah Koefisien Gini. Pada Maret 2019 ketimpangan pendapatan dari Provinsi Jawa Tengah adalah meningkat dibandingkan dengan ketimpangan pendapatan pada September 2018. Untuk mengurangi ketimpangan pendapatan tersebut, pemerintah memfokuskan pada peningkatan belanja pemerintah di bidang bantuan sosial antara lain Bantuan Pangan Non Tunai (BPNT). Demikianlah, penelitian ini bertujuan untuk menghitung dan mendapatkan angka penurunan Koefisien Gini sebagai hasil dari penerapan program BPNT di Provinsi Jawa Tengah Indonesia. Penelitian ini menggunakan metode Counter Factual Analysis (CFA) dan data Susenas Maret 2019. Penelitian ini menyimpulkan bahwa penerapan program BPNT pada 2019 cukup efektif dalam menurunkan tingkat ketimpangan pendapatan di Provinsi 
Jawa Tengah Indonesia yaitu mampu menurunkan Koefisien Gini Provinsi Jawa Tengah sebesar -1.20\%. Penerapan program BPNT mampu membuat pengeluaran penduduk kelompok bawah meningkat lebih cepat dibandingkan dengan penduduk kelompok atas maupun menengah. Penerapan program BPNT mengubah peta tingkat ketimpangan pendapatan dari 35 kabupaten/kota di Provinsi Jawa Tengah Indonesia tetapi tidak mengubah peta tingkat ketimpangan pendapatan antara perkotaan dan perdesaan di Provinsi Jawa Tengah Indonesia. Selain itu, penerapan program BPNT di Provinsi Jawa Tengah Indonesia belum bisa mengubah kategori ketimpangan pendapatan di Provinsi Jawa Tengah Indonesia yaitu tetap berada dalam kategori sedang atau moderat. Penelitian ini merekomendasikan untuk dilakukan perbaikan dari sisi sasaran penerima $B P N T$, kualitas sumber daya manusia pendamping, waktu penerimaan bantuan, kualitas beras, dan kesiapan e-warong di 35 kabupaten/kota di Provinsi Jawa Tengah Indonesia.

Kata Kunci: Bantuan Pangan Non Tunai, Ketimpangan Pendapatan, Koefisien Gini, Counter Factual Analysis.

\section{INTRODUCTION}

BPS Statistics Province of Central Java Indonesia (2019) explains that one measure of income inequality that is often used is the Gini Coefficient. The value of the Gini Coefficient ranges from 0 to 1 . The higher the value of the Gini Coefficient, the higher the inequality.

BPS Statistics Province of Central Java Indonesia (2019) explained that in March 2019 the Gini Coefficient of Central Java Province was 0.361 , slightly increased by 0.004 points compared to the Gini Coefficient in September 2018. Thus, in March 2019 income inequality of Central Java Province was increasing compared to income inequality in September 2018, so it must be reduced.

World Bank Indonesia (2016) explains that some level of inequality can be a positive thing because those who work hard, innovate and take risks are rewarded for their efforts. However, income inequality becomes unfair when not everyone has the same initial opportunities. Inequality that is allowed to grow and not addressed can have serious consequences, namely slower economic growth and poverty reduction and an increased risk of conflict. Most Indonesians are now aware of this issue and believe that the Government must take action, identify problems and set goals.

World Bank Indonesia (2016) states that high inequality can be avoided. Policy makers can reduce inequality by addressing factors beyond the control of individuals that exacerbate inequality. World Bank Indonesia (2016) recommends the main action to reduce inequality, namely using taxes and government budgets to reduce inequality today and in the future. Fiscal policy should focus on increasing government spending on infrastructure, health and education, social assistance and social security. Fiscal policies that focus on social assistance include Non-Cash Food Assistance (Bantuan Pangan Non Tunai/BPNT).

Taufiqo (2018) succeeded in calculating the impact of BPNT distribution on reducing the level of inequality, namely the distribution of BPNT resulting in a more even distribution of household income with the Gini Coefficient falling by 0.2208 points.

However, research by Taufiqo (2018) has limitations, namely measuring the decline in the 2018 Gini Coefficient as a result of the BPNT program distributed in 2018 using the 2008 Indonesia SocioEconomic Balance System (SNSE) or Social Accounting Matrices (SAM) data where the distribution pattern of household income and expenditure between 2008 with 2018 much different.

Therefore, this study tries to provide an alternative calculation of the impact of the BPNT program on the reduction of the Gini Coefficient in 2019 using Susenas data for March 2019 and the distribution pattern of BPNT in 2019. Using the Counter Factual Analysis (CFA) method and Susenas data for March 2019, this research will result in a reduction rate of the Gini Coefficient much closer to the real state. In contrast to Taufiqo's research (2018) which calculates the decrease in the national Gini Coefficient as a result of implementing BPNT nationally, this study calculates the decrease in the Gini Coefficient of Central Java Province as a result of implementing the BPNT program in Central Java Province. 
Thus, the question of this research is what is the decrease in the Gini Coefficient as a result of the implementation of the BPNT program in the Central Java Province of Indonesia? This study aims to calculate and obtain a reduction in the Gini Coefficient as a result of the implementation of the BPNT program in the Central Java Province of Indonesia.

\section{METHODS}

This study uses the Counter Factual Analysis (CFA) method which is also used by the World Bank in calculating Commitment to Equity (CEQ). Counter Factual Analysis calculates the impact of programs (social assistance and subsidies) on income inequality and poverty. Counter Factual Analysis is comparing the actual conditions (with government intervention) with conditions without government intervention (Darinda and Moechtar, 2019).

This study uses the Counter Factual Analysis method to calculate the impact of the BPNT program in 2019 on reducing the level of income inequality or the Gini Coefficient in March 2019 in the Province of Central Java, Indonesia. The software used is Stata 15. The data used is the March 2019 Susenas data (BPS Statistics Indonesia, 2019a).

First, this study calculates the 2019 Gini Coefficient of the Central Java Province of Indonesia before the implementation of the BPNT program. Second, this study calculates the 2019 Gini Coefficient of the Central Java Province of Indonesia after the implementation of the BPNT program. Finally, this study calculates the decrease in the Gini Coefficient of the Central Java Province of Indonesia as a result of the implementation of the BPNT program in Central Java Province. This study uses the formula of Gini Coefficient as explained by Syamsuddin (2011) and Firdaus \& Witomo (2014):

Where:

$$
\mathrm{G}=1-\sum_{i=1}^{n}\left(X_{t+1}+X i\right)\left(Y i+Y_{t+1}\right)
$$

$\mathrm{G}=$ Gini Coefficient

$\mathrm{Xi}=$ the proportion of household cumulative number at $\mathrm{t}$ level

$\mathrm{Yi}=$ the proportion of the total revenues

$\mathrm{N}=$ the total of household number.

\section{RESULTS AND DISCUSSIONS}

This study found that the implementation of the BPNT program in 2019 was able to reduce the Gini Coefficient of Central Java Province by $-1.20 \%$. Before the BPNT program was implemented, the Gini Coefficient of Central Java Province in March 2019 was 0.3649. After the BPNT program was implemented, the Gini Coefficient decreased to 0.3605 or there was a decrease in the Gini Coefficient of $-1.20 \%$ or -0.0044 points as a result of the implementation of the BPNT program, ceteris paribus, namely by assuming that the factors affecting the Gini Coefficient other than the BPNT program are fixed or unchanged.

The decrease in the Gini Coefficient of Central Java Province by $-1.20 \%$ is a great achievement because it is the highest decrease in Gini Coefficient of 34 provinces in Indonesia as a result of the implementation of the BPNT program. For information, the five provinces with the largest decrease in Gini Coefficients as a result of the implementation of the BPNT program are Central Java Province ($1.20 \%)$, DI Yogyakarta Province (-1.05\%), East Java Province (-0.86\%), Gorontalo Province (- $0.59 \%)$, and West Nusa Tenggara Province (-0.56\%).

Changes in the level of population's income inequality are strongly influenced by the large variation in expenditure changes between population groups. If the change in expenditure of the lower group of population is faster than the upper and middle class population, the expenditure inequality or income inequality will decrease (BPS Statistics Indonesia, 2019b).

The implementation of the BPNT program in Central Java Province succeeded in reducing the Gini Coefficient of Central Java Province so that it could be stated that the implementation of the BPNT program in Central Java Province was able to make the expenditures of the lower class group of population increase faster than the expenditures of the upper and middle group of population. 
Based on the classification by Oshima, the Gini Coefficient for March 2019 before the BPNT program was implemented was 0.3649 which indicates a moderate level of inequality. According to Oshima, the value of the Gini Coefficient is divided into three levels. The Gini Coefficient value less than 0.3 is included in the low inequality category, the Gini Coefficient value between 0.3 to 0.5 is included in the moderate category, and a Gini Coefficient value greater than 0.5 is said to be in high inequality (BPS Statistics City of Yogyakarta, 2017).

After the BPNT program was implemented, the Gini Coefficient of Central Java Province in March 2019 was 0.3605 which is included in the moderate category. Thus, it can be stated that the implementation of the BPNT program in Central Java Province does not change the category of income inequality in Central Java Province, namely that it remains in the moderate category.

Before the BPNT program was implemented, the Gini Coefficient of Central Java Province in March 2019 was 0.3649 . There are 8 districts/cities that have a Gini Coefficient above 0.3649 before the implementation of the BPNT program, namely City of Magelang (0.4147), City of Semarang (0.3884), District of Temanggung (0.3879), District of Magelang (0.3859), District of Wonosobo (0.3760), City of Surakarta (0.3735), District of Blora (0.3718), and District of Jepara (0.3664).

After the BPNT program was implemented, the Gini Coefficient of Central Java Province in March 2019 was 0.3605 . There are 9 districts/cities that have a Gini Coefficient above 0.3605 after the implementation of the BPNT program, namely City of Magelang (0.4118), City of Semarang (0.3871), District of Temanggung (0.3826), District of Magelang (0.3809), City of Surakarta (0.3710), District of Wonosobo (0.3690), District of Blora (0.3657), District of Jepara (0.3618), and District of Sukoharjo (0.3617).

From the explanation above, it can be seen that before the implementation of the BPNT program, there were 8 districts/cities that had a Gini Coefficient above the Gini Coefficient of Central Java Province. After the BPNT program was implemented, there were 9 districts/cities that had a Gini Coefficient above the Gini Coefficient of Central Java Province. Thus, it can be stated that the implementation of the BPNT program changed the map of the level of income inequality of 35 districts/cities in the Central Java Province of Indonesia in March 2019.

The Gini Coefficient before the implementation of the BPNT program and after the implementation of the BPNT program and the reduction in the Gini Coefficient by 35 regencies/cities in Central Java Province, Indonesia can be seen in table 1.

Table 1. The Decrease of Gini Coefficient as A Result of BPNT Program in the Province of Central Java March 2019

\begin{tabular}{clcccc}
\hline \multirow{2}{*}{ No } & \multicolumn{1}{c}{ District/City } & \multicolumn{2}{c}{ Gini Coefficient } & \multicolumn{2}{c}{$\begin{array}{c}\text { Decrease in Gini } \\
\text { Coefficient }\end{array}$} \\
\cline { 3 - 6 } & & Before BPNT & $\begin{array}{c}\text { After } \\
\text { BPNT }\end{array}$ & Percentage & Point \\
\hline 1 & District of Cilacap & 0.3509 & 0.3457 & $-1.49 \%$ & -0.0052 \\
2 & District of Banyumas & 0.3585 & 0.3537 & $-1.33 \%$ & -0.0048 \\
3 & District of Purbalingga & 0.3367 & 0.3304 & $-1.87 \%$ & -0.0063 \\
4 & District of Banjarnegara & 0.3467 & 0.3425 & $-1.21 \%$ & -0.0042 \\
5 & District of Kebumen & 0.3190 & 0.3136 & $-1.69 \%$ & -0.0054 \\
6 & District of Purworejo & 0.3639 & 0.3578 & $-1.66 \%$ & -0.0060 \\
7 & District of Wonosobo & 0.3760 & 0.3690 & $-1.87 \%$ & -0.0071 \\
8 & District of Magelang & 0.3859 & 0.3809 & $-1.31 \%$ & -0.0050 \\
9 & District of Boyolali & 0.3545 & 0.3493 & $-1.48 \%$ & -0.0052 \\
10 & District of Klaten & 0.3585 & 0.3527 & $-1.62 \%$ & -0.0058 \\
11 & District of Sukoharjo & 0.3645 & 0.3617 & $-0.77 \%$ & -0.0028 \\
12 & District of Wonogiri & 0.3435 & 0.3387 & $-1.39 \%$ & -0.0048 \\
13 & District of Karanganyar & 0.3441 & 0.3412 & $-0.82 \%$ & -0.0028 \\
14 & District of Sragen & 0.3395 & 0.3347 & $-1.43 \%$ & -0.0049
\end{tabular}




\begin{tabular}{|c|c|c|c|c|c|}
\hline \multirow{2}{*}{ No } & \multirow{2}{*}{ District/City } & \multicolumn{2}{|c|}{ Gini Coefficient } & \multicolumn{2}{|c|}{$\begin{array}{c}\text { Decrease in Gini } \\
\text { Coefficient }\end{array}$} \\
\hline & & Before BPNT & $\begin{array}{l}\text { After } \\
\text { BPNT }\end{array}$ & Percentage & Point \\
\hline 15 & District of Grobogan & 0.3326 & 0.3264 & $-1.85 \%$ & -0.0061 \\
\hline 16 & District of Blora & 0.3718 & 0.3657 & $-1.62 \%$ & -0.0060 \\
\hline 17 & District of Rembang & 0.3573 & 0.3502 & $-2.00 \%$ & -0.0071 \\
\hline 18 & District of Pati & 0.3028 & 0.2996 & $-1.08 \%$ & -0.0033 \\
\hline 19 & District of Kudus & 0.3240 & 0.3218 & $-0.69 \%$ & -0.0022 \\
\hline 20 & District of Jepara & 0.3664 & 0.3618 & $-1.26 \%$ & -0.0046 \\
\hline 21 & District of Demak & 0.2894 & 0.2853 & $-1.42 \%$ & -0.0041 \\
\hline 22 & District of Semarang & 0.3344 & 0.3324 & $-0.59 \%$ & -0.0020 \\
\hline 23 & District of Temanggung & 0.3879 & 0.3826 & $-1.38 \%$ & -0.0054 \\
\hline 24 & District of Kendal & 0.3600 & 0.3565 & $-0.97 \%$ & -0.0035 \\
\hline 25 & District of Batang & 0.3055 & 0.3018 & $-1.20 \%$ & -0.0037 \\
\hline 26 & District of Pekalongan & 0.3091 & 0.3061 & $-0.96 \%$ & -0.0030 \\
\hline 27 & District of Pemalang & 0.3356 & 0.3310 & $-1.35 \%$ & -0.0045 \\
\hline 28 & District of Tegal & 0.3249 & 0.3220 & $-0.88 \%$ & -0.0029 \\
\hline 29 & District of Brebes & 0.3463 & 0.3411 & $-1.52 \%$ & -0.0052 \\
\hline 30 & City of Magelang & 0.4147 & 0.4118 & $-0.70 \%$ & -0.0029 \\
\hline 31 & City of Surakarta & 0.3735 & 0.3710 & $-0.66 \%$ & -0.0025 \\
\hline 32 & City of Salatiga & 0.3574 & 0.3559 & $-0.42 \%$ & -0.0015 \\
\hline 33 & City of Semarang & 0.3884 & 0.3871 & $-0.32 \%$ & -0.0012 \\
\hline 34 & City of Pekalongan & 0.3065 & 0.3046 & $-0.62 \%$ & -0.0019 \\
\hline \multirow[t]{2}{*}{35} & City of Tegal & 0.3414 & 0.3389 & $-0.74 \%$ & -0.0025 \\
\hline & Province of Central Java & 0.3649 & 0.3605 & $-1.20 \%$ & -0.0044 \\
\hline
\end{tabular}

Source: BPS Statistics Indonesia (2019a), calculated.

Before the BPNT program was implemented, the urban Gini Coefficient in Central Java Province (0.3860) was greater than the rural Gini Coefficient in Central Java Province (0.3227). After the implementation of the BPNT program, urban Gini Coefficient in Central Java Province (0.3826) was still greater than the rural Gini Coefficient of Central Java Province (0.3176). Thus, the implementation of the BPNT program does not change the map of the level of income inequality between urban and rural areas in Central Java Province Indonesia.

This is supported by the urban and rural Gini Coefficients of 35 districts/cities in Central Java Province. Both before the BPNT program was implemented, and after the BPNT program was implemented, the urban Gini Coefficient in 35 districts/cities in Central Java Province was always greater than the rural Gini Coefficient in 35 districts/cities in Central Java Province.

From the above explanation, it can be stated that the implementation of the BPNT program is quite effective in reducing the Gini Coefficient in Central Java Province. The district/city with the highest Gini Coefficient decrease as a result of the implementation of the BPNT program was District of Rembang with a decrease in the Gini Coefficient of $-2.00 \%$ or -0.0071 points. Then in order of the highest is District of Wonosobo with a decrease in the Gini Coefficient of $-1.87 \%$ or -0.0071 points, District of Purbalingga with a decrease in the Gini Coefficient of $-1.87 \%$ or -0.0063 points, District of Grobogan with a decrease in the Gini Coefficient of $-1.85 \%$ or -0.0061 points, District of Kebumen with a decrease in the Gini Coefficient of $-1.69 \%$ or -0.0054 points, District of Purworejo with a decrease in the Gini Coefficient of $-1.66 \%$ or -0.0060 points, District of Blora with a decrease in the Gini Coefficient of $-1.62 \%$ or -0.0060 points, District of Klaten with a decrease in the Gini Coefficient of $-1.62 \%$ or 0.0058 points, District of Brebes with a decrease in the Gini Coefficient of $-1.52 \%$ or -00052 points, and the tenth place is District of Cilacap with a decrease in the Gini Coefficient of $-1.49 \%$ or -0.0052 points. 
The explanation above which says that the implementation of the BPNT program is able to reduce the level of income inequality as evidenced by the decrease in the Gini Coefficient in line with the explanation from the Minister of Social Affairs of the Republic of Indonesia. The Minister of Social Affairs of the Republic of Indonesia stated that BPNT was effective in reducing the level of income inequality due to four factors: first, BPNT is based on an Integrated Database (Basis Data Terpadu/BDT) which is regularly updated in coordination with the cities or districts. Second, BPNT realizes financial inclusion by encouraging changes in the behavior of Beneficiary Families (Keluarga Penerima Manfaat/KPM) to recognize non-cash transactions. Third, BPNT actively involves the community for social work where there are tens of thousands of workers for BPNT, including Kelurahan Social Welfare Workers (Tenaga Kesejahteraan Sosial Kelurahan/TKSK) and other social assistants, there are productive businesses such as e-warong where KPM takes BPNT. Fourth, because BPNT has a wide reach and every year the number of recipients increases, where in 2018 BPNT recipients have more than 10 million KPM and according to the direction of the President of the Republic of Indonesia that in 2019 all 15.6 million KPM are entitled to receive BPNT. In addition, the Director General of Social Protection and Security of the Indonesian Ministry of Social Affairs stated that the trend of graduated KPM (i.e., no longer accepting BPNT because the level of income and welfare was already high) had increased from 230,000 KPM in 2018 to 640,000 KPM which had achieved independent prosperous graduation (graduasi sejahtera mandiri) in 2019 (Jayaputra, et al., 2019).

The effectiveness of the implementation of the BPNT program also occurs in other areas as explained by the research of Wiwit, Sulistyaningsih, and Kamil (2020) who found that the implementation of monitoring and evaluation of the BPNT program in City of Batu, East Java Province, has implemented the principles of monitoring and evaluation and has been going quite well by the Food Social Assistance (Bantuan Sosial Pangan/BSP) companion. The BPNT program is considered to have been right on target so that it can accelerate the implementation of poverty reduction. Inhibiting factors in monitoring and evaluating the BPNT program are the capacity of Human Resources (HR) and time.

In addition to research by Wiwit, Sulistyaningsih, and Kamil (2020), research by Dini, Nurmalisa, and Halim (2018) also explains the same thing, namely that the effectiveness of the implementation of the Non-Cash Food Assistance (BPNT) program in Gulak Galik Village, Sub-district of Teluk Betung Utara, City of Bandar Lampung, Lampung Province, based on the community's perception of BPNT program beneficiaries, has been running effectively with the following percentages: $62 \%$ accuracy of program targets is in the effective category, $44 \%$ of program socialization is in the fairly effective category, $79 \%$ of program objectives are in the effective category, and program monitoring of $56 \%$ was in the fairly effective category. For this reason, the effectiveness of the implementation of the BPNT program in Gulak Galik Village needs to be further improved by frequently updating program beneficiary data as well as providing maximum service and program information.

Rosaliana and Hardjati (2019) explain that the implementation of the BPNT program in SubDistrict of Wonocolo, City of Surabaya, East Java Province has been carried out in a timely manner, both the distribution of food aid funds from the government to Beneficiary Families (Keluarga Penerima Manfaat/KPM) and the distribution of e-warong operational assistance funds from the government to managers e-warong. The accuracy in making choices in the implementation of the BPNT program in Sub-District of Wonocolo was identified based on the accuracy in determining the choice of targets and the accuracy in determining the choice of needs. However, the accuracy of using the Prosperous Family Card (Kartu Keluarga Sejahtera/KKS) as an instrument in the BPNT program in SubDistrict of Wonocolo still requires improvement.

In his research on the implementation of the BPNT program in Sisir Village, Sub-District of Batu, City of Batu, East Java Province, Anwar, Ati, and Pindahanto (2020) concluded that in terms of problem characteristics, the implementation of the BPNT program through e-warong in Sisir Village was still zero in terms of problems, in term of program characteristics, the implementation of the BPNT program is considered to be right on target because the human resources in Sisir Village are deemed to have fulfilled their duties and functions as regulated, and in terms of environmental variables, the socio-economic conditions of the community in the BPNT program have supported its implementation. 
In his research on the relationship between the BPNT program and the level of welfare of the people of Gampong of Kutatinggi, Sub-District of Blangpidie, District of Aceh Barat Daya, Aceh Province, Ikhsan, Zulfan, and Nusuary (2019) concluded that quantitatively there is a relationship between the implementation of Non-Cash Food Assistance (BPNT) and the welfare of the poor in Gampong of Kutatinggi. Qualitatively, the community is satisfied with the assistance provided by the government through the BPNT program for less prosperous people.

Research by Fadlurrohim, Nulhaqim, and Sulastri (2019) shows that the distribution of NonCash Food Assistance using the banking system can support the productive behavior of beneficiaries and increase program transparency and accountability for ease of controlling, monitoring and reducing irregularities. Increased productivity of BPNT recipients will in turn increase income so that income inequality decreases.

Research by Wiyaka and Murti (2019) proves that the social assistance provided by the government through BPNT greatly provides new business opportunities for micro and medium entrepreneurs because BPNT program can encourage the growth of KUBE e-warong managed by BPNT recipients in Sub-District of Gerih and Sub-District of Geneng, District of Ngawi, Province of East Java, which in turn increases the independence of the poor in rural areas. An economically independent society will find it easier to increase income so that the level of inequality will decrease. Most of the BPNT recipients stated that the foodstuffs in the form of rice and eggs received were of high quality and that the supply was guaranteed according to the predetermined schedule. The implementation of the BPNT program was successful in improving the accuracy in terms of the amount and timing of aid distribution, reducing queues, faster disbursement processes, and significantly reducing technical problems encountered in the field.

From table 1 it is known that the implementation of the BPNT program in City of Semarang has had little success in reducing the Gini Coefficient so that it only succeeds in reducing the Gini Coefficient by $-0.32 \%$ or -0.0012 points after the implementation of the BPNT program. The same thing happened to the City of Salatiga and District of Semarang. Why does the implementation of the BPNT program in the City of Semarang, the City of Salatiga and the District of Semarang play only a minor role in reducing the Gini Coefficient? Several researchers have conducted studies on why the implementation of the BPNT program is not or less effective in its distribution or is less effective in reducing the Gini Coefficient.

Rachman, Agustian, and Wahyudi (2018) explain that the implementation of Rastra and BPNT is deemed necessary to improve in terms of target recipients, timing of receiving assistance, quality of rice, and e-warong readiness in all regions. The process of transforming the subsidy pattern (Beras Sejahtera/Rastra) into a food aid pattern (BPNT) must also be carried out in stages according to the readiness of the infrastructure. In addition, considering that Rastra and BPNT policies are closely related to the role and capacity of Bulog (Badan Urusan Logistik/Indonesian Bureau of Logistics) in absorbing grain-rice from farmers and maintaining rice price stabilization, the government needs to increase the Government's Rice Reserves (Cadangan Beras Pemerintah/CBP).

Meanwhile, Tiara and Mardianto (2019) explained that the process of implementing the NonCash Food Assistance (BPNT) program in City of Palembang, South Sumatra Province was not yet effective because several problems and obstacles were still found due to a lack of budget for implementing programs at the Social Service of Government of City of Palembang and the lack of Human Resources (HR) capable of running and supervising the BPNT program. In the implementation of the BPNT program, there are still many aspects that have not been running properly, such as the assistance process that KPM feels are still lacking, combo card errors that result in loss of KPM balances, the number of BPNT e-warong is not many and is not evenly distributed throughout the village, and does not meet the stages assistance activities that have been arranged in the BPNT program.

The results of Pathony and Deda's research (2019) show that in terms of policy objectives, the implementation of the BPNT program has not been right on target in the selection of e-warong owners. All e-warong owners in Sub-District of Subang, District of Subang, West Java Province are not from BPNT beneficiaries but from existing Brilink agents. From the resource side, it is known that the 
completeness of the facilities and infrastructure is still inadequate and hinders the implementation of BPNT policies through e-warong. There is still a need for the addition of e-warongs as facilities and infrastructure in the BPNT distribution policy so that there is no accumulation of KPM in 10 e-warongs in Sub-District of Subang. Communication between Sub-District of Subang and Social Service of Government of District of Subang in determining the requirements and criteria for e-warong has not been optimal.

Research by Laurentcia and Yusron (2021) regarding the evaluation of the Non-Cash Food Assistance program in Sub-District of Nanggalo, City of Padang, West Sumatra Province concluded that the implementation of the BPNT program in Sub-District of Nanggalo in terms of achieving program objectives was not optimal because there were still problems related to data collection mechanisms, distribution mechanisms, and the mechanism for utilizing aid funds. Meanwhile, the impact of the implementation of the BPNT program in Sub-District of Nanggalo is considered sufficient to improve the quality of life for pre-prosperous communities.

In his research on the implementation of the BPNT program in Sub-District of Kanigaran, City of Probolinggo, East Java Province, Yunus (2019) gave several suggestions, namely: (a) there needs to be good coordination by executors and stakeholders so that data invalidity will not occur, (b) it is necessary quick responses by related officers in dealing with EDC machine facility problems, (c) there is a need for evaluation regarding implementers who cannot implement a good public service attitude, (d) there is a need for more assistance regarding social conditions that are less supportive with the implementation of the Non-Cash Food Assistance program (BPNT), and (e) there is a need for transparency and tighter supervision so that irregularities do not occur.

The limitation of this study is that this study uses ceteris paribus assumption so this study is assuming that the factors affecting the Gini Coefficient other than the BPNT program are fixed or unchanged.

\section{CONCLUSIONS}

This study concludes that the implementation of the BPNT program in 2019 is quite effective in reducing the level of income inequality in Central Java Province, which is able to reduce the Gini Coefficient of Central Java Province by $-1.20 \%$. The implementation of the BPNT program was able to make the expenditure of the lower class population increase faster than the expenditure of upper and middle class population. The implementation of the BPNT program changed the map of income inequality levels from 35 districts/cities in Central Java Province. The implementation of the BPNT program does not change the map of the level of income inequality between urban and rural areas in Central Java Province. In addition, the implementation of the BPNT program in Central Java Province has not been able to change the category of income inequality in Central Java Province, namely that it remains in the moderate category.

The effectiveness of the implementation of the BPNT program in reducing the Gini Coefficient is due, among other things, to the Integrated Database (Basis Data Terpadu/BDT) which is the database for BPNT recipients which is regularly updated, BPNT realizes financial inclusion by encouraging changes in the behavior of Beneficiary Families (Keluarga Penerima Manfaat/KPM) to recognize noncash transactions, BPNT involves the community to be actively involved in social work where there are tens of thousands of workers involved in implementing the BPNT program, and BPNT has a wide reach and every year the number of recipients increases. In addition, the implementation of the BPNT program has implemented the principles of monitoring and evaluation, which are quite effective in terms of program targeting accuracy, program socialization, program objectives, and program monitoring.

However, improvements in the implementation of the BPNT program still need to be done so that this study recommends improvements in terms of the target BPNT recipients, the quality of companion human resources, the time for receiving assistance, the quality of rice, and the readiness of e-warong in 35 districts/cities in Central Java Province. 


\section{ACKNOWLEDGEMENT}

The author would like to thank Allah SWT because of His gift the author was able to complete this paper. Author also thanks the family for always supporting the writer's activities. Author also thank colleagues in the Fiscal Policy Agency of the Ministry of Finance for discussions and guidance so that the author can complete this paper.

\section{REFERENCES}

Anwar, D. P., Ati, N. U., \& Pindahanto, R. (2020). Implementasi Program Bantuan Pangan Non Tunai (BPNT) Dinas Sosial Dalam Menanggulangi Kemiskinan di Kelurahan Sisir Kecamatan Batu Kota Batu. Jurnal Respon Publik Vol.14 No.3, 1 - 7.

BPS Statistics City of Yogyakarta. (2017). Gini Ratio 2016 of City of Yogyakarta. Yogyakarta: BPS Statistics City of Yogyakarta.

BPS Statistics Indonesia. (2019a). Survey of Social and National Economy (Susenas) March 2019. Jakarta: BPS Statistics Indonesia.

BPS Statistics Indonesia. (2019b). Statistic Official Broadcast No.57/07/Th.XXII, 15 July 2019: Expenditure Inequality of Indonesia March 2019. Jakarta: BPS Statistics Indonesia.

BPS Statistics Province of Central Java Indonesia. (2019, July 15). Expenditure Inequality of Population of Central Java Province March 2019. Statistic Official Broadcast No.48/07/33/Th.XIII, 15 July 2019, pp. 1 - 4.

Darinda, D., \& Moechtar, A. (2019). Analisis Dampak Bansos dan Subsidi atas Kemiskinan dan Ketimpangan. In T. Falyanti, H. Amir, \& Y. Abimanyu, Seri Analisis Kebijakan Fiskal - Kapita Selekta Kebijakan Fiskal dan Makroekonomi Terhadap Pertumbuhan Ekonomi yang Berkelanjutan dan Berkeadilan: Analisis Nasional dan Regional (pp. 61 - 98). Bogor: PT Penerbit IPB Press.

Dini, A. R., Nurmalisa, Y., \& Halim, A. (2018). Efektivitas Pelaksanaan Program Bantuan Pangan Non Tunai (BPNT) Di Kelurahan Gulak Galik. Jurnal Kultur Demokrasi Vol.5 No.13, 1 - 12.

Fadlurrohim, I., Nulhaqim, S. A., \& Sulastri, S. (2019). Implementasi Program Bantuan Pangan Non Tunai (Studi Kasus di Kota Cimahi). Social Work Journal Vol.9 No.2, 122 - 129.

Firdaus, M., \& Witomo, C. M. (2014). Analysis of Welfare and Household Income Inequality of Large Pelagic Fishers in Sendang Biru, Malang District, East Java. Jurnal Sosial Ekonomi Kelautan dan Perikanan (Sosek KP) Vol.9 No.2, 155 - 168.

Ikhsan, T., Zulfan, \& Nusuary, F. M. (2019). Hubungan Pelaksanaan Bantuan Pangan Non Tunai (BPNT) dengan Kesejahteraan Masyarakat Miskin di Gampong Kutatinggi Aceh Barat Daya. Jurnal IImiah Mahasiswa FISIP Unsyiah Vol.4 No.2, Juni 2019, 1 - 12.

Jayaputra, A., Syawie, M., Huruswati, I., Purwanto, A., Muhtar, Pujianto, B., . . Wibow, A. (2019). Kontribusi Program Kementerian Sosial Dalam Penurunan Angka Kemiskinan. Jakarta: Puslitbangkesos Kementerian Sosial RI.

Laurentcia, S., \& Yusron, R. (2021). Evaluasi Program Bantuan Pangan Non Tunai Dalam Penanggulangan Kemiskinan di Kecamatan Nanggalo Kota Padang. Journal of Civic Education Vol.4 No.1 Tahun 2021, 7 - 17.

Pathony, T., \& Deda, C. (2019). Implementasi Kebijakan Bantuan Pangan Non Tunai Melalui Elektronik Warung Gotong Royong (E-Warong) di Kecamatan Subang Kabupaten Subang. The World of Public Administration Journal (WPAJ) Vol.1 Issue.2, Desember 2019, 187 - 205.

Rachman, B., Agustian, A., \& Wahyudi. (2018). Efektivitas dan Perspektif Pelaksanaan Program Beras Sejahtera (Rastra) dan Bantuan Pangan Non Tunai (BPNT). Analisis Kebijakan Pertanian Vol.16 No.1, Juni 2018, 1 - 18.

Rosaliana, A., \& Hardjati, S. (2019). Efektivitas Pelaksanaan Program Bantuan Pangan Non Tunai (BPNT) di Kecamatan Wonocolo Kota Surabaya. Public Administration Journal Vol.2 No.2, 96 - 110.

Syamsuddin. (2011). Perhitungan Indeks Gini Ratio dan Analisis Kesenjangan Distribusi Pendapatan Kabupaten Tanjung Jabung Barat Tahun 2006-2010. Jurnal Paradigma Ekonomika Vol.1 No.4 Oktober 2011, 83 - 102. 
Taufiqo, F. U. (2018). Dampak Bantuan Pangan Non Tunai Terhadap Distribusi Pendapatan Rumah Tangga: Analisis Sistem Neraca Sosial Ekonomi Indonesia. Journals of Economics Development Issues (JEDI) Vol.1 No.2, 26 - 32.

Tiara, R., \& Mardianto. (2019). Efektivitas Program Bantuan Pangan Non Tunai (BPNT) di Kota Palembang. Demography Journal of Sriwijaya (DeJos) Vol.3 No.1, Januari 2019, 37 - 46.

Wiwit, Sulistyaningsih, T., \& Kamil, M. (2020). Monitoring dan Evaluasi Kebijakan Program Bantuan Pangan Non Tunai (BPNT) Dalam Penanggulangan Kemiskinan di Kota Batu. Government: Jurnal Ilmu Pemerintahan Vol.13 No.1 Januari 2020, 1 - 12.

Wiyaka, A., \& Murti, E. (2019). Implementasi Program Bantuan Pangan Non Tunai (BPNT) Dalam Perlindungan Sosial di Kecamatan Gerih dan Kecamatan Geneng Kabupaten Ngawi Tahun 2018. Seminar Nasional Sistem Informasi 2019, 19 September 2019 (pp. 1773 - 1778). Malang: Fakultas Teknologi Informasi UNMER Malang.

World Bank Indonesia. (2016). Wider Inequality: Why, What's the Impact, and What's the Solution? Jakarta: World Bank Indonesia.

Yunus, E. Y. (2019). Implementasi Program Bantuan Pangan Non Tunai (BPNT) di Kecamatan Kanigaran Kota Probolinggo. Reformasi: Jurnal Ilmiah IImu Sosial dan Ilmu Politik Vol.9 No.2, 138 - 152. 